\title{
Applying art to scientific research: Reasons for using an original method
}

\author{
Carlos G. Musso, M.D.PhD. ${ }^{a}$, Débora Dricas, Magister ${ }^{b}$ and \\ Henry González-Torres, Magister ${ }^{c}$
}

\begin{abstract}
Art, by virtue of its symbolic power, may function as a cognitive instrument and even as an aid in the scientific research process, especially in the phase of hypothesis generation and data analysis given its ability to induce creative and intuitive thinking. In this article, we propose a method to put such concept into practice based on the exposure of scientists to collective artistic activities in protected settings, a methodology developed from the experiences described by renowned artists and scientists.

Key words: research, science, art, cognition, symbolism.
\end{abstract}

http: / / dx.doi.org/10.5546/ aap.2018.eng.353

To cite: Musso C, Dricas D, González-Torres H. Applying art to scientific research: Reasons for using an original method. Arch Argent Pediatr 2018;116(5):353-358.

a. Department of Human Sciences, Instituto Universitario del Hospital Italiano de Buenos Aires, Argentina.

b. Universidad del Salvador-Argentine Dental Association (Asociación Odontológica Argentina).

c. Universidad Simón Bolívar, Facultad de Ciencias de la Salud. Barranquilla, Colombia.

E-mail address:

Carlos G. Musso, M.D.PhD: carlos.musso@

hospitalitaliano.org.ar

Funding:

None.

Conflict of interest: None.

Received: 2-11-2018 Accepted: 2-19-2018

\section{ART AS AN INSTRUMENT OF COGNITION}

Spoken language is, for humans, a cognitive instrument to address the world because it allows them to segment the world into multiple categories (signs), whose value is bestowed by their practical utility and the consensus agreed by speakers. However, humans also approach the world through the senses, projecting outlines of essential images (symbols) based on their individual bodily experience and the heritage of the human species. ${ }^{1,2}$

In this regard, Nelson Goodman and Jean-Luc Nancy state that art and science offer humans different systems to widen such knowledge by providing the possibility of perceiving themselves and, from there, shape the world..$^{3,4}$ Jacques Rancière claims that art helps to "design new configurations of what can be seen, said, and thought," and enables to gain knowledge from ignorance by promoting creativity. The theory of "education based on art" does not attempt to turn scientists into artists but to offer them artistic languages during the research process by stimulating sensitivity, experimentation, and creative imagination. As proclaimed by "conceptual art," the main point does not lie in the resulting physical object but in the concepts and ideas that gave rise to, and emerged from, it. ${ }^{5}$ Charles Percy Snow points out that the current separation between science and art is detrimental and restrains cultural development. ${ }^{6}$ For this reason, by the end of the 20th century, live beings started to become part of artistic expressions, and collaborations between artists and scientists took place at biotechnology laboratories. ${ }^{7}$ In this setting, contemporary discussions regarding the science method (Morin), the question of what is science (Khun), the interdependence between the inner world and the laboratory (Latour) give account of a new way of creating knowledge (Fried Schnitman). ${ }^{8-11}$

Based on the preceding, it is observed that the grounds for the separation of art and science are the differences in the strategies to gain knowledge of (represent) the world; therefore, the discursive contexts would be based on different referential expectations: verifiable in the case of science and metaphorical in that of art. However, the world they explore is the same, so such methodological differences, far from justifying the lack of collaboration, highlight their potential benefits. ${ }^{12}$ 


\section{ART AS AN INSTRUMENT OF RESEARCH: FOUNDATIONS \\ Art and philosophy}

The characteristics of art endorse its use in research, such as its correspondence to natural language, its role as an external trigger, and its participation in emotional cognition. ${ }^{2,13-15}$

Philosopher Friedrich Schelling stated that nature expresses itself through its configurations, where concept lives in the form, and this is the language of the natural world (SchellingMaturana). The laws of the natural world function quietly and may be revealed when they surface in the human consciousness. Schelling claims that the symbolic forms of art may be able to evince the connection between nature and the psyche, through its embodiment during artistic expression because natural and artistic languages are both based on image. Therefore, an interpretative circle takes place where nature contains concept in the form, and concept reveals itself to consciousness through the artistic symbol. ${ }^{13,14}$

According to biologist Maturana, the nervous system functions by making internal correlations, which are independent from the setting (closed system); therefore, although there are external stimuli in place (images and words), the body does not act in response to such stimuli but as a result of its own stimulus-triggered function. Rather than acting as behavior generators, external stimuli may be the triggers of latent, pre-existing (folded) behaviors that are later expressed (unfolded). Artistic images (symbols) may trigger inner programs, which are perceived as intuition or internal convictions. . $^{14,15}$

Emotion always permeates the cognitive process and is an integral part of it. This is because reason is unable to wholly determine human actions and beliefs; in consequence, such shortage is complemented by emotion (Dewey), defining the range of information that reason takes into consideration for analysis, so that emotion carries relevance and sets the goals and boundaries of reasoning. In addition, emotion promotes heuristics, creativity, and innovation. The heuristic mechanisms of art include metaphoric ability, based on the merger of existing images to obtain new ones, which allows to transcend conceptual borders. By recalling emotion, art helps to guide and impregnate scientific thinking. ${ }^{15,16}$

\section{Art and creativity}

According to John Dewey, when humans conceive, produce and / or enjoy a work of art, their ability to recognize aesthetics emerges (intuition), thus causing a significant experience that promotes analysis and reflection. Therefore, considering this view of the world, art takes center stage within culture, and art products are not merely the objects of decoration and/or financial speculation but, basically, the promoters of human development. ${ }^{17}$

Hans-Georg Gadamer considers that the aesthetic experience involves the hermeneutical mechanisms of understanding, interpretation, and implementation. Through it, individuals become aware of the horizon of their interpretation and, from there, they go out to meet what the work of art conveys; therefore, both horizons may then come together. Individuals compare what they have just perceived from the artwork to what they received from other works of art, texts, and past experiences. As a consequence, the past is posed again through the present situation and the exploration of strategies to change what is given by default to create something new. In such merger of horizons, dialog takes place as an exchange of questions and answers. By accepting that there is a question, we recognize that there is something questionable, opinions are reviewed, and new concepts are promoted. ${ }^{18}$

David Perkins states that the creative act, in the fields of both science and art, is a natural prolongation of everyday mental abilities: perception, understanding, memory, etc. This means that creative people do not have different intellectual abilities but, based on the same resources as the rest, they reach innovative solutions. In addition, Perkins considers that innovation may occur through the practice of design because the ability to design is present in the large majority of the people. This suggests a model that induces creative thinking based on design, which would allow to mentally separate and regroup things to generate new ideas. ${ }^{19}$

Lastly, Gastón Bachelard claims that the difficulty to understand a new phenomenon is based on the individuals' psychological conditions resulting from their prior knowledge. In his opinion, it is not possible to wipe the slate clean of previously acquired knowledge and it takes an effort to take down the obstacles that bewilder the mind, hinder the perception of problems and/or the search for a solution. Artistic practice may help to remove such mental barriers. $^{20}$ 


\section{ART AS AN INSTRUMENT OF RESEARCH: THE METHODOLOGY}

Throughout the history of art, it has been repeatedly documented that it has managed to gain new interpretative perspectives and descriptions of the world phenomena long before science did. ${ }^{21}$ Art and science even share heuristic features when creating styles or proposing work hypothesis, respectively. ${ }^{2}$ Based on the preceding, in this article, we propose to integrate both forms of cognitive approach (signs and symbols) to enhance and strengthen scientific research. This epistemological perspective is based on the hypothesis that since art functions as a trigger of inner certainties, i.e., of a knowledge that resides in the human subconscious by the mere fact that humans are an integral part of the world, it may help to surface knowledge to the conscious plane (Wittgenstein). ${ }^{22}$ Precisely based on this concept, we propose that symbol-loaded artistic images may activate chains of association that could encourage the development of innovative ideas during the research process so that they may work as "keys" to open the doors of the subconscious. ${ }^{1,2}$

In relation to how this proposal for research activity may be specifically put in practice (method), painter Salvador Dalí and psychiatrist Carl Jung described procedures that may serve as models, and there is also a series of highlysymbolic, ancient images, i.e., that have a great capacity to work as external triggers and that have been described by psychology, anthropology, and art, and which may help to generate a creative setting (Perkins-Nachmanovitch), an essential background in the development of a method capable of integrating art and scientific research. 16,21-32

\section{The paranoiac-critical method (Salvador Dalí)}

Salvador Dalí developed an art-based research technique called the "paranoiac-critical" method. It consists of the observation of different images where the spontaneous navigation from one image to the next takes place through metonymic associations (shift from one image to another) or metaphoric associations (having new ideas through the merger with old ones), with no control of reason, aesthetics or moral. It means letting yourself be influenced by shapes, a process where one image leads to another, and so on, until discovering the hidden secret of the object of research.
Dalí demonstrated the effectiveness of this cognitive method when he famously analyzed The Angelus by Millet (Figure 1). The painting shows two peasants who have stopped working in the field one afternoon to pray. Salvador Dalí always thought the painting had a hidden meaning and set to discover it, thus conceiving a method to achieve it. This is how he started observing different types of rocks, either menhirs in Finistère or pebbles on the beach of Cadaqués, whose irregular shapes resulted extremely evocative of the couple in The Angelus. He then perceived a sign of death in the image, which was reinforced by the repeated painting experimentations he did of the couple's image. Lastly, he sensed the hidden meaning of the painting: the couple was praying in honor of their dead, buried child. A subsequent X-ray analysis done by the Louvre Museum showed the presence of a little casket at the feet of the woman, and an investigation of Millet's letters documented that he had removed the casket from the image following the advice of a friend who had said that melodramatic paintings were no longer fashionable in Paris. ${ }^{2}$

It is worth noting that watching cinematographic images may act as a "machine that induces paranoiac-critical thinking," because a film has, at the mercy of the realism of its images, the ability to make people think and to awaken the human consciousness. However, it would have to be a movie with minimal film montage because, as pointed out by Benjamín, instead of stimulating the liberation of thoughts, film editing conditions it by over-determining

FIgURE 1. The Angelus, by Millet

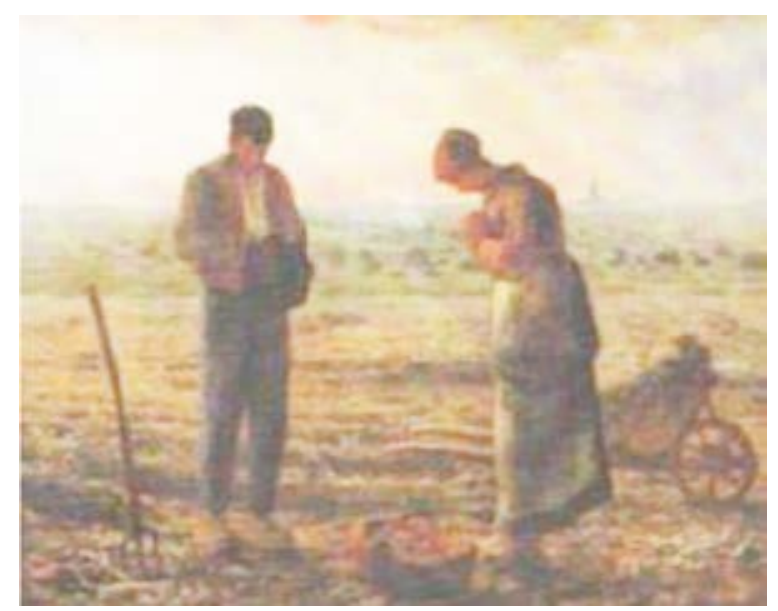


meaning. For this reason, a film that stimulates the liberation of associative thoughts should mimic a dream or a surrealist movie, where "montage" is replaced by "montrage" (Deleuze). ${ }^{24}$

\section{The alchemical method (Carl Jung)}

According to Carl Jung, the purpose of the opus alquimicum, or work of medieval alchemists, was not to change base metals into gold but, actually, to find knowledge, not only because they could learn a lot from their chemical experiments but, basically, because alchemy practice projected psychic content and this allowed them to stimulate the development of enlightening intuition. Medieval alchemists had a saying: "our gold is not common gold" (aurum nostrum non est aurum vulgi), which meant that the "gold" they were after was not material (metal) but spiritual (knowledge). During the experiment, alchemists projected their subconscious onto the matter, which turned the subconscious (emergence) inadvertently evident (projection). Jung himself applied these principles when practicing stone carving as a means to develop his psychological theories.

In addition, Jung described the existence of a series of images that represented classical oneiric symbols, also capable of encouraging the psychic projection phenomenon described above. The most well-known designs included geometric figures (circle, spiral, triangle, square, diamond, cross, zig zag), colors (white, black, yellow, red), Earth and firmament images (sea, rainbow, sun, moon, sky, mountain, cavern, abyss), live beings (tree, flower, serpent, bird, wild animal, garden), engineering works (stairs, road, palace, fountain, clock), and archetypal images (father, mother, angel, demon, death). ${ }^{15}$

It is not by chance that the large majority of oneiric-archetypal images that Jung described as capable of stimulating the projection of subconscious knowledge (trigger) match accurately those that the Neolithic mind expressed in cave paintings, those that witch doctors perceive during ecstatic experiences, and those that visual arts have employed as part of their language throughout universal history. ${ }^{26-32}$ All these are arcane symbols, which may serve as true bridges between the subconscious (hidden knowledge) and the matter (artworks). During the passage, a transformation process (alchemical method) would take place which would result in the advent of such information onto consciousness (revealed knowledge).
Physicist Wolfgang Pauli and Carl Jung, partially based on the ideas of biologist Paul Kammerer and philosopher Arthur Schopenhauer, attributed (hypothesis) the sudden and transient emergence of a correspondence between the awareness of an unconscious knowledge and the perception of an image outside the mind to the existence of an alleged correspondence law, based on behavior patterns that rule the natural world and promote these significant coincidences, which would be the basis of intuitive thinking. ${ }^{15}$

\section{The creative atmosphere of Perkins-Nachmanovitch}

Creative thinking may emerge from both the surroundings of a person (environment or circumstances) and his/her inner side; therefore, any barrier that could block it should be removed. David Perkins highlights the need to build an enabling environment so that artistic practice may promote broad cognitive experiences, review different perspectives and, as a consequence, reach original and creative reflections. Although creativity implies putting new ideas in practice in a research and reflection process, for this to occur, art should be present or an artistic expression should be practiced, and this requires a strong sensory anchorage in a supportive emotional setting. ${ }^{33}$

According to Stephen Nachmanovitch, the field of action for the emergence of creativity should be mediated by recreation, exploration, and experimentation. In the case of recreation, what matters is not what you do but how you do it, in a setting where a flexible, sensitive communicative interaction takes place and where there is tolerance of mistakes and ambiguous situations. $^{34}$

\section{Proposal of a new methodology}

Considering the typical steps of the scientific method (i.e., detection of a problem, development of an explanatory hypothesis, selection of materials and the method used to attempt to falsify the hypothesis, conduct of the study, achievement and discussion of results, and finally, the approach of a conclusion) and based on what we have analyzed above that art could be potentially used in scientific research to facilitate the emergence of an intuition onto consciousness that is capable of answering the study questions, then, it is reasonable to determine that the research steps that would be most benefited 
from art would be those that require creative thinking, i.e., hypothesis development and result discussion. Based on the experiences described here regarding Salvador Dalí and Carl Jung, and Perkins' and Nachmanovitch's creative atmosphere, we propose that the following methodology could be used when designing a method to put these concepts in practice, interweave them in the research process, and assess them.

In the period during which the investigator develops his/her research hypothesis or data discussion, he/she should collaborate with other investigators, who may not necessarily share his/ her discipline, sharing an environment where they are all exposed to different works of art and / or do different artistic activities so as to foster intuitive, creative, and innovative thinking. Such exposure may be achieved through the design of a protected environment, preferably in natural settings (Schelling, Heidegger) that are equipped to this end, where investigators may share a series of not mutually exclusive activities, such as:

- Participating in visual art activities (painting, drawing, ceramics, etc.).

- Listening to music of the great composers.

- Watching films of a high symbolic content.

In relation to this last resource, purposely designed short films with nature- or culturerelated images of a high symbolic content could be devised.

The possibility of confirming the existence of a significantly larger and more original scientific production by scientists exposed to the influence of this type of artistic activities in protected environments may corroborate the usefulness of art in the scientific research process.

In short, art, by virtue of its symbolic, cognitive, and innovative power, stimulates creative thinking and may help to enhance the process of hypothesis development, the design of the research question, and the analysis of results as part of the research process. To this end, we propose an original method based on the exposure of scientists to collective artistic activities in protected, specially-designated settings.

\section{REFERENCES}

1. Musso CG. La intersección de las paralelas: arte y ciencia en un único proceso cognitivo. Hacia una nueva forma de investigar. Rev Hosp Ital B Aires 2012; 32(1):1-2.

2. Castro S, Marcos A. Arte y ciencia. Mundos convergentes. Madrid: Plaza y Valdés; 2010.

3. Goodman N. Maneras de hacer mundos. Madrid: Hackett Publishing; 1990.
4. Nancy JL.El artehoy. Buenos Aires:Prometeo Libros; 2015.

5. Rancière J. El espectador emancipado. Pontevedra: Ellago; 2012.

6. Snow CP. Las dos culturas. Buenos Aires: Nueva Visión; 2000.

7. Machado A. El paisaje mediático. Sobre el desafío de las poéticas tecnológicas. Buenos Aires: Nueva Librería; 2009.

8. Morin E. El método III El conocimiento del conocimiento. Madrid: Cátedra; 1999.

9. Kuhn T. La estructura de las revoluciones científicas. México: Fondo de Cultura Económica; 2004.

10. Latour B. Nunca fuimos modernos. Ensayo de antropología simétrica. Buenos Aires: Siglo XXI; 2007.

11. Fried Schnitman D, Schnitman J.Resolución de conflictos. Nuevos diseños, nuevos contextos. Buenos Aires: Granica; 2000.

12. Ricoeur P. Historia y narratividad. Barcelona: Paidós; 1999.

13. Schelling F. La relación del arte con la naturaleza. Madrid: Globus; 2012.

14. Maturana-Romesín H, Pörksen B. Del ser al hacer. Los orígenes de la biología del conocer. Buenos Aires: Gránica; 2015.

15. Musso CG, Baez F, Elias MJ, et al. The principle of synchronicity-equivalence and chronomedicine: relevance and methodological exploration. Arch Argent Pediatr 2017;115(4):309-10.

16. Musso CG, Enz P. Semiótica médica. Principios lingüísticos y comunicacionales de uso médico. Buenos Aires: Delhospital ediciones; 2007.

17. Dewey J. El arte como experiencia. Barcelona: Paidós; 2008.

18. Gadamer HG. Verdad y método Fundamentos de una Filosofía, Hermenéutica, Obras completas. Tübingen: Mohr; 1986.

19. Perkins D. Las obras de la mente. México: Fondo de Cultura Económica; 1988.

20. Bachelard G. La formación del espíritu científico. Contribución al psicoanálisis del conocimiento objetivo. México: Siglo XXI; 2000.

21. Leherer J. Poust y la neurociencia. Barcelona: Paidós; 2010.

22. Wittgenstein L. Investigaciones filosóficas. Barcelona: Crítica; 2004.

23. DalíS. El mito trágico de “El Ángelus" de Millet. Barcelona: Tusquets; 2002.

24. González D, Llevadot L, Saez Tajafuerce B. Kierkegaard y las artes. Pensar la creación. Barcelona: UOC; 2015.

25. Jung CG. Psicología y alquimia. Buenos Aires: Santiago Rueda; 1957.

26. Lewis-Williams D. La mente en la caverna. Madrid: Akal; 2005.

27. Lewis-Williams D, Pearce D. Dentro de la mente neolítica. Madrid: Akal; 2009.

28. Eliade M. El chamanismo y las técnicas arcaicas deléxtasis. México: Fondo de Cultura Económica; 1960.

29. Clothes J, Lewis-Williams D. Los chamanes de la prehistoria. Barcelona: Planeta; 2001.

30. Reichel-Dolmatoff G. Orfebrería y chamanismo: Un estudio iconográfico del Museo del Oro del Banco de la República, Colombia. Bogotá: Museo del Oro; 2014.

31. Pineda Camacho R. El poder de los hombres que vuelan. Gerardo Reichel Dolmatoff y su contribución a la teoría del Chamanismo. Tabula Rasa (Bogotá) 2003; 1:15-47.

32. Arola R. Custiones simbólicas. Las formas básicas. Barcelona: Herder; 2015.

33. Perkins D. Las obras dela mente. México: Fondo de Cultura Económica; 1988.

34. Nachmanovitch S. Free Play. La improvisación en la vida y en el arte. Buenos Aires: Barrendero; 2011. 